\title{
Effect of seed treatments, spacing and season of sowing on yield and quality of coriander (Coriandrum sativum L.) under rain shelter
}

\author{
V U Anjukrishna*, N Mini Raj, P Anitha \& A K Aneesha \\ College of Horticulture, Vellanikkara, Kerala Agricultural University, Thrissur, Kerala, India-680 656 \\ *E-mail: anjukrishna481@gmail.com
}

Received 20 August 2020; Revised 14 May 2021; Accepted 14 May 2021

\begin{abstract}
Coriander is an important herb \& seed spice. The yield of coriander is influenced by the agronomic practices adopted during cultivation. This study was carried out in the Department of Plantation Crops and Spices, College of Horticulture, Vellanikkara, Kerala Agricultural University from July 2019 to March 2020 to analyse the effect of seed treatments, spacing and growing season on yield and quality of coriander leaves under rain shelter. The experiment was laid out in factorial completely randomized design (FCRD) with three replications. The study revealed that, presowing seed treatments improved the growth and yield of coriander than untreated seeds. The impact of seed treatments was conspicuous at the time of harvest on growth, yield and quality parameters. Hydropriming for $24 \mathrm{~h}$ was found to be the best presowing seed treatment followed by seed treatment with $\mathrm{GA}_{3} 50 \mathrm{ppm}$ for $8 \mathrm{~h}$. A closer spacing of $10 \times 10 \mathrm{~cm}$ which accommodated more plants per unit area recorded the highest biomass and herbage yield plot $^{-1}$. October - December season was found to be the best for obtaining better growth and yield in leaf coriander. Hence, the study concluded that, hydropriming for $24 \mathrm{~h}$ or seed treatment with GA 50 ppm for $8 \mathrm{~h}$, a closer spacing of $10 \times 10 \mathrm{~cm}$ and October - December season are the ideal combination for the best performance of variety CO-4 for leaf purpose under rain shelter in the tropical moist humid climate.
\end{abstract}

Keywords: coriander, $\mathrm{GA}_{3^{\prime}}$ growing season, hydropriming, NAA, rain shelter, seed treatments, spacing

\section{Introduction}

Coriander (Coriandrum sativum $\mathrm{L}$ ) is one of the world's oldest spices whose use history can be traced back to $5000 \mathrm{BC}$. In many dishes the word is known for the dried seeds rather than to the whole plant and it is an un avoidable seed and herbal spice in all cuisines world over. Coriander is a member of carrot family Apiaceae or Umbelliferae and is indigenous to Southern Europe and Mediterranean region.

India is the largest producer of coriander seeds with 5, 83,000 ha area and 7, 84,000 MT of 
annual production. It is mainly cultivated in Rajasthan, Madhya Pradesh, Andhra Pradesh, Gujarat, Tamil Nadu and Karnataka.

Coriander leaves display an impressive nutritional profile, as it is high in proteins and dietary fibres, with negligible cholesterol and saturated fats. Besides, they are a rich source of vitamins and minerals like vitamin $\mathrm{A}$, vitamin C, vitamin E, zinc, calcium, magnesium, iron and phosphorus. Besides, the leaves also possess powerful antioxidants like carotenoids, flavonoids and anthocyanins which promote the anti-inflammatory and anti-microbial functions.

Though coriander can be cultivated throughout the year, the demand for coriander leaves is high during summer. Production as well as quality of the produce highly depends on the seasonal variations. Kerala is a high rainfall state with diverse agro climatic conditions. High rainfall and relative humidity result in biotic stresses which inhibit the growth of herbal spices like coriander. The concept of rain shelter, the naturally ventilated polyhouse will be ideal for the herbal spice production in Kerala.

Seed priming is a technique of presowing seed treatment with physical, chemical or biological substances to improve the growth and yield. Hydropriming and seed treatments with plant growth regulators enhance the germination, growth, yield and quality of many crops. Direct sowing of coriander also gives good germination percentage, but heterogeneous maturity of coriander seeds produce uneven and poor germination. The plant density is important to obtain maximum biomass yield of leafy vegetables. Optimizing the plant densities will not only improve the growth and yield but also reduce the input cost in terms of seed rate and fertilizers without reducing the yield and quality. The growing season is the period when crops grow successfully, exhibiting maximum growth and yield. Coriander can be grown for leaf purpose throughout the year but, the extreme variations in the climatic factors limit the growth and development during vegetative phase which lead to the incidence of pests and diseases as well as inferior quality. Hence, the present study was undertaken to evaluate the effect of seed treatments, spacing and growing season on growth, yield and quality of coriander variety $\mathrm{CO}-4$.

\section{Materials and methods}

The field trial was carried out in rainshelter in the Plantation farm of Department of Plantation Crops and Spices, College of Horticulture, Vellanikkara during July 2019 to March 2020. The seeds of coriander variety CO4 , a dual purpose variety released from Tamil Nadu Agricultural University were collected from TNAU Coimbatore. There were two experiments conducted during two seasons i.e. July - September and October - December. Prior to the field preparation, lime was applied in the field at the rate of $600 \mathrm{~kg} \mathrm{ha}^{-1}$. Raised beds of $1 \mathrm{~m}^{2}$ area were prepared. Basal dose of $5 \mathrm{t} \mathrm{ha}^{-1}$ FYM, 20:10:10 kg ha-1 NPK $+10 \mathrm{~kg} \mathrm{ha}^{-1} \mathrm{~N}$ (top dressing) at 20 DAS were given.

\section{Experiment No. 1. Standardization of seed treatments}

The experiment consisted of five seed treatments including the control as given below.

$\mathrm{T}_{1}$ : Splitting of seeds only

$\mathrm{T}_{2}$ : Splitting of seeds and soaking in water for $12 \mathrm{~h}$

$\mathrm{T}_{3}$ : Splitting of seeds and soaking in water for $24 \mathrm{~h}$

$\mathrm{T}_{4}$ : Splitting of seeds and soaking in $\mathrm{GA}_{3} 50$ ppm for $8 \mathrm{~h}$

$\mathrm{T}_{5}$ : Splitting of seeds and soaking in NAA 20 ppm for $8 \mathrm{~h}$ 


\section{Experiment No. 2. Standardization of spacing}

The experiment was laid out with three row $x$ plant spacings as given below.

$\mathbf{T}_{1}: 30 \times 10 \mathrm{~cm}\left(33\right.$ plants $\left.\mathrm{m}^{-2}\right)$

$\mathbf{T}_{2}: 20 \times 10 \mathrm{~cm}\left(50\right.$ plants $\left.\mathrm{m}^{-2}\right)$

$\mathbf{T}_{3}: 10 \times 10 \mathrm{~cm}\left(100\right.$ plants $\left.\mathrm{m}^{-2}\right)$

Plant densities varied with the spacings.

\section{Morphological and biochemical observations}

The plants were harvested before the emergence of serrated leaves i.e., at 40 days after sprouting. All growth, yield and quality parameters were recorded at the time of harvest. Ascorbic acid content of freshly harvested leaves was estimated by titration method (Rao \& Deshpande 2005). The chlorophyll content was estimated by the Dimethyl Sulfoxide Method as per Hiscox \& Isrealstam (1979). The essential oil present in the coriander leaves was extracted using Clevenger apparatus (Clevenger 1928).

\section{Statistical analysis}

The experiment was laid out in Factorial completely randomized design (FCRD) with three replications. The effect of different treatments was quantified, and the level of significance was determined by the analysis of variance (ANOVA) and least significant difference $(\mathrm{LSD}<0.05)$ among mean values. Duncan's multiple range test was used to compare the treatment means.

\section{Results and discussion}

Seed treatments, spacing and season had significant influence on germination, growth, yield and quality of coriander variety $\mathrm{CO}-4$.

\section{Effect of seed treatments}

Seed treatments had significant influence on sprouting as seen from data presented in Table 1. The seeds subjected to priming exhibited early sprouting than untreated seeds. Seeds hydroprimed for $24 \mathrm{hr}$ and primed with $\mathrm{GA}_{3}$ 50 ppm and NAA 20 ppm for $8 \mathrm{hr}$ recorded early germination. Priming might have improved the germination by accelerating imbibition which enhances the multiplication of radicle cells (Maroufi et al. 2011). The plant growth regulators such as $\mathrm{GA}_{3}$ and NAA are widely used in agriculture for boosting the productivity. $\mathrm{GA}_{3}$ induces the hydrolytic enzymes which triggers the weakness of seed coat by stimulating gene expression responsible for cell expansion and modification as reported in Arabidopsis by Finkelstein et al. (2008).

Different seed treatments had significant influence on growth characters like plant height and number of leaves (Table 1). Among the various treatments, the highest plant height $(27.67 \mathrm{~cm})$ and highest number of leaves per plant (8.77) were observed in $\mathrm{GA}_{3} 50 \mathrm{ppm}$ treatment followed by NAA $20 \mathrm{ppm}$ and hydropriming treatments. The magnitude of increase in plant height was more pronounced when the plants attained harvest maturity. Increase in plant height might be due to the stem elongation and cell division enhancement by $\mathrm{GA}_{3}$. Gibberellin is a phytohormone that is responsible for regulation of plant height (Bano et al. 2016). GA treatments are also effective for enhancing the vegetative growth by increasing the plasticity of the cell wall (Singh et al. 2012). The results obtained in the study are in line with the findings of Kumar et al. (2018); Haokip et al. (2016), Meena et al. (2006) and Verma (2002) in coriander. Application of NAA also enhanced the growth of coriander plants. It could be attributed to the improved photosynthetic ability of the plants (Haokip et al. 2016).

The yield parameters showed significant variation among the different seed treatments (Table 2). Hydropriming for $24 \mathrm{~h}$ was found to be the best seed treatment for yield attributing characters such as biomass yield plot $^{-1}$ and herbage yield plot $^{-1}$ followed by GA $\mathrm{A}_{3}$ at $50 \mathrm{ppm}$. The significant increase in biomass and green leaf yield might be due to the stimulation of 
Table 1. Effect of seed treatments and season of sowing on growth parameters of coriander variety CO-4

\begin{tabular}{|c|c|c|c|c|c|c|c|c|c|}
\hline \multirow[t]{2}{*}{ Treatment /Season } & \multicolumn{3}{|c|}{ Germination (days) } & \multicolumn{3}{|c|}{ Plant height at harvest $(\mathrm{cm})$} & \multicolumn{3}{|c|}{$\begin{array}{c}\text { Number of leaves at } \\
\text { harvest }\end{array}$} \\
\hline & $\mathrm{S}_{1}$ & $\mathrm{~S}_{2}$ & Mean & $\mathrm{S}_{1}$ & $\mathrm{~S}_{2}$ & Mean & $\mathrm{S}_{1}$ & $\mathrm{~S}_{2}$ & Mean \\
\hline $\mathrm{T}_{1}$ & 7.00 & 7.33 & $7.17^{\mathrm{a}}$ & 21.94 & 24.78 & $23.36^{\mathrm{d}}$ & $6.27^{\mathrm{c}}$ & $9.33^{b}$ & $7.80^{\mathrm{b}}$ \\
\hline $\mathrm{T}_{2}$ & 6.67 & 7.00 & $6.83^{\mathrm{ab}}$ & 22.78 & 25.25 & $24.02^{\mathrm{c}}$ & $6.33^{c}$ & $9.40^{\mathrm{b}}$ & $7.87^{\mathrm{b}}$ \\
\hline $\mathrm{T}_{3}$ & 6.33 & 6.33 & $6.33^{c}$ & 23.07 & 25.97 & $24.52^{\mathrm{c}}$ & $6.40^{c}$ & $9.60^{\mathrm{b}}$ & $8.00^{\mathrm{b}}$ \\
\hline $\mathrm{T}_{4}$ & 6.33 & 6.33 & $6.33^{c}$ & 26.32 & 29.01 & $27.67^{\mathrm{a}}$ & $6.67^{c}$ & $10.87^{a}$ & $8.77^{\mathrm{a}}$ \\
\hline $\mathrm{T}_{5}$ & 6.33 & 6.33 & $6.33^{c}$ & 24.49 & 27.68 & $26.08^{b}$ & $6.53^{c}$ & $10.53^{\mathrm{a}}$ & $8.53^{\mathrm{a}}$ \\
\hline Mean & 6.53 & 6.67 & & $23.72^{\mathrm{b}}$ & $26.54^{\mathrm{a}}$ & & $6.44^{\mathrm{b}}$ & $9.94^{\mathrm{a}}$ & \\
\hline CD (Season) & & NS & & & 0.69 & & & 0.25 & \\
\hline CD (Treatments) & & 0.62 & & & 1.10 & & & 0.40 & \\
\hline $\begin{array}{l}\text { CD (Season } \times \\
\text { Treatments) }\end{array}$ & & NS & & & NS & & & 0.57 & \\
\hline
\end{tabular}

$\mathrm{T}_{1}$ : splitting of seeds only; $\mathrm{T}_{2}$ : splitting of seeds and soaking in water for $12 \mathrm{~h} ; \mathrm{T}_{3}$ : splitting of seeds and soaking in water for $24 \mathrm{~h} ; \mathrm{T}_{4}$ : splitting of seeds and soaking in $\mathrm{GA}_{3} 50 \mathrm{ppm}$ for $8 \mathrm{~h} ; \mathrm{T}_{5}$ : splitting of seeds and soaking in NAA 20 ppm for $8 \mathrm{~h}$; $\mathrm{S}_{1}$ : July - September; $\mathrm{S}_{2}$ : October - December

seedling emergence and early establishment of plants. Zarei et al. (2011) have reported the positive effects of hydropriming in chickpea and Ogbuehi et al. (2013) reported the influence of hydropriming on seed yield of groundnut.

The quality parameters also varied among the seed treatments (Table 3). Vitamin C content (65.54 mg $100 \mathrm{~g}^{-1}$ ) was found to be highest when the seeds were treated with $\mathrm{GA}_{3} 50 \mathrm{ppm}$. Gibberellin also plays a vital role in sugar metabolism. The ascorbic acid is synthesized from the sugars and high vitamin $C$ content might be due to the increased synthesis of sugars and due to the transformation of organic acids to sugars (Jangid et al. 2018). Active involvement of plant growth regulators leads to the breakdown of organic acids and sugars as suggested by Singh \& Singh (2017). Increased vitamin C content with the application of $\mathrm{GA}_{3}$ has also been reported by Kumar et al. (2012) in strawberry. Presowing

Table 2. Effect of seed treatments and season on yield parameters of coriander variety CO-4

\begin{tabular}{|c|c|c|c|c|c|c|}
\hline \multirow[t]{2}{*}{ Treatment/ Season } & \multicolumn{3}{|c|}{ Biomass yield plot ${ }^{-1}\left(\mathrm{~g} \mathrm{~m}^{-2}\right)$} & \multicolumn{3}{|c|}{ Green leaf yield plot ${ }^{-1}\left(\mathrm{~g} \mathrm{~m}^{-2}\right)$} \\
\hline & $\mathrm{S}_{1}$ & $\mathrm{~S}_{2}$ & Mean & $\mathrm{S}_{1}$ & $\mathrm{~S}_{2}$ & Mean \\
\hline $\mathrm{T}_{1}$ & $65.20^{g}$ & $333.63^{\mathrm{e}}$ & $199.42^{\mathrm{e}}$ & $58.50^{\mathrm{g}}$ & $317.17^{\mathrm{e}}$ & $187.83^{\mathrm{e}}$ \\
\hline $\mathrm{T}_{2}$ & $81.57^{\mathrm{fg}}$ & $409.97^{c}$ & $245.77^{\mathrm{c}}$ & $73.33^{\mathrm{fg}}$ & $393.83^{c}$ & $233.58^{c}$ \\
\hline $\mathrm{T}_{3}$ & $95.73^{\mathrm{f}}$ & $527.87^{a}$ & $311.80^{\mathrm{a}}$ & $83.67^{\mathrm{f}}$ & $513.00^{\mathrm{a}}$ & $298.33^{\mathrm{a}}$ \\
\hline $\mathrm{T}_{4}$ & $94.13^{\mathrm{f}}$ & $453.67^{\mathrm{b}}$ & $273.90^{\mathrm{b}}$ & $80.33^{\mathrm{f}}$ & $434.33^{b}$ & $257.58^{b}$ \\
\hline $\mathrm{T}_{5}$ & $71.43^{g}$ & $367.63^{\mathrm{d}}$ & $219.53^{\mathrm{d}}$ & $59.67^{g}$ & $349.67^{\mathrm{d}}$ & $204.67^{\mathrm{d}}$ \\
\hline Mean & $81.61^{\mathrm{b}}$ & $418.55^{\mathrm{a}}$ & & $71.20^{\mathrm{b}}$ & $401.60^{a}$ & \\
\hline CD (Season) & & 9.65 & & & 6.93 & \\
\hline CD (Treatments) & & 15.26 & & & 10.96 & \\
\hline CD (Season $\times$ Treatments) & & 21.59 & & & 15.50 & \\
\hline
\end{tabular}

$\mathrm{T}_{1}$ : splitting of seeds only; $\mathrm{T}_{2}$ : splitting of seeds and soaking in water for $12 \mathrm{~h} ; \mathrm{T}_{3}$ : splitting of seeds and soaking in water for $24 \mathrm{~h} ; \mathrm{T}_{4}$ : splitting of seeds and soaking in $\mathrm{GA}_{3} 50 \mathrm{ppm}$ for $8 \mathrm{~h} ; \mathrm{T}_{5}$ : splitting of seeds and soaking in NAA 20 ppm for $8 \mathrm{~h}$; $\mathrm{S}_{1}$ : July - September; $\mathrm{S}_{2}$ : October - December 
Table 3. Effect of seed treatments and season on quality parameters of coriander variety CO-4

\begin{tabular}{|c|c|c|c|c|c|c|c|c|c|}
\hline \multirow[t]{2}{*}{ Treatment/ Season } & \multicolumn{3}{|c|}{$\begin{array}{l}\text { Vitamin C content } \\
\left(\mathrm{mg} 100 \mathrm{~g}^{-1}\right)\end{array}$} & \multicolumn{3}{|c|}{ Volatile oil (\%) } & \multicolumn{3}{|c|}{$\begin{array}{l}\text { Total chlorophyll content } \\
\left(\mathrm{mg} \mathrm{g}^{-1}\right)\end{array}$} \\
\hline & $\mathrm{S}_{1}$ & $S_{2}$ & Mean & $\mathrm{S}_{1}$ & $\mathrm{~S}_{2}$ & Mean & $\mathrm{S}_{1}$ & $\mathrm{~S}_{2}$ & Mean \\
\hline $\mathrm{T}_{1}$ & $18.50^{\mathrm{f}}$ & $64.00^{c}$ & $41.25^{c}$ & 0.1 & 0.1 & 0.1 & $1.427^{\mathrm{f}}$ & $1.924^{c}$ & $1.676^{\mathrm{d}}$ \\
\hline $\mathrm{T}_{2}$ & $21.17^{\mathrm{f}}$ & $65.33^{c}$ & $43.25^{c}$ & 0.1 & 0.1 & 0.1 & $1.495^{\mathrm{e}}$ & $1.979^{\mathrm{b}}$ & $1.737^{c}$ \\
\hline $\mathrm{T}_{3}$ & $29.17^{\mathrm{e}}$ & $73.33^{b}$ & $51.25^{\mathrm{b}}$ & 0.1 & 0.1 & 0.1 & $1.554^{\mathrm{d}}$ & $2.195^{\mathrm{a}}$ & $1.875^{\mathrm{a}}$ \\
\hline $\mathrm{T}_{4}$ & $43.75^{\mathrm{d}}$ & $81.33^{a}$ & $65.54^{\mathrm{a}}$ & 0.1 & 0.1 & 0.1 & $1.317^{\mathrm{g}}$ & $2.203^{a}$ & $1.760^{c}$ \\
\hline $\mathrm{T}_{5}$ & $18.75^{\mathrm{f}}$ & $65.33^{c}$ & $42.04^{c}$ & 0.1 & 0.1 & 0.1 & $1.455^{\mathrm{ef}}$ & $2.178^{a}$ & $1.817^{\mathrm{b}}$ \\
\hline Mean & $26.27^{b}$ & $69.87^{a}$ & & 0.1 & 0.1 & & $1.450^{\mathrm{b}}$ & $2.096^{\mathrm{a}}$ & \\
\hline CD (Season) & & 1.44 & & & NS & & & 0.025 & \\
\hline CD (Treatments) & & 2.28 & & & NS & & & 0.039 & \\
\hline $\begin{array}{l}\text { CD (Season } \times \\
\text { Treatments) }\end{array}$ & & 3.23 & & & NS & & & 0.056 & \\
\hline
\end{tabular}

$\mathrm{T}_{1}$ : splitting of seeds only; $\mathrm{T}_{2}$ : splitting of seeds and soaking in water for $12 \mathrm{~h} ; \mathrm{T}_{3}$ : splitting of seeds and soaking in water for $24 \mathrm{~h} ; \mathrm{T}_{4}$ : splitting of seeds and soaking in $\mathrm{GA}_{3} 50 \mathrm{ppm}$ for $8 \mathrm{~h} ; \mathrm{T}_{5}$ : splitting of seeds and soaking in NAA 20 ppm for 8 h; $\mathrm{S}_{1}$ : July - September; $\mathrm{S}_{2}$ : October - December

seed treatment had significant effect on total chlorophyll content also. Hydropriming for 24 $\mathrm{h}$ recorded highest total chlorophyll content $\left(1.875 \mathrm{mg} \mathrm{g}^{-1}\right)$ in fresh leaves. Mohajeri et al. (2017) reported that presowing seed treatment with water for 12 hours recorded highest total chlorophyll content in Phaseolus vulgaris. Similarly, hydropriming for different durations significantly increased the chlorophyll ' $b$ ' content of Moringa oleifera leaves (Nouman et al. 2012). The essential oil content was found to be unaffected by various seeds treatments.

\section{Effect of spacing}

Data presented in Table 4 revealed non significant effect of spacing on sprouting of seeds whereas, spacing markedly influenced plant height and number of leaves. Among the three row spacings, closer spacing of $10 \times 10$ $\mathrm{cm}$ recorded significantly highest plant height $(25.02 \mathrm{~cm})$ and number of leaves $(9.10)$ at harvest followed by medium spacing of $20 \times 10$ $\mathrm{cm}$ ( $23.83 \mathrm{~cm}$ and 9.00 respectively). Plant might have adjusted its canopy in the vertical space

Table 4. Effect of spacing and season on growth parameters of coriander variety CO-4

\begin{tabular}{|c|c|c|c|c|c|c|c|c|c|}
\hline \multirow[t]{2}{*}{ Treatment/ Season } & \multicolumn{3}{|c|}{ Germination (days) } & \multicolumn{3}{|c|}{ Plant height $(\mathrm{cm})$} & \multicolumn{3}{|c|}{ Number of leaves } \\
\hline & $\mathrm{S}_{1}$ & $\mathrm{~S}_{2}$ & Mean & $\mathrm{S}_{1}$ & $\mathrm{~S}_{2}$ & Mean & $\mathrm{S}_{1}$ & $\mathrm{~S}_{2}$ & Mean \\
\hline $\mathrm{T}_{1}$ & 7.33 & 6.00 & 6.67 & 20.65 & 23.39 & $22.02^{c}$ & $5.93^{c}$ & $9.53^{b}$ & $7.73^{b}$ \\
\hline $\mathrm{T}_{2}$ & 7.33 & 6.33 & 6.83 & 19.65 & 28.01 & $23.83^{b}$ & $6.33^{c}$ & $11.67^{\mathrm{a}}$ & $9.00^{\mathrm{a}}$ \\
\hline $\mathrm{T}_{3}$ & 7.00 & 6.33 & 6.67 & 21.37 & 28.67 & $25.02^{\mathrm{a}}$ & $6.40^{c}$ & $11.80^{\mathrm{a}}$ & $9.10^{\mathrm{a}}$ \\
\hline Mean & 7.22 & $6.22^{\mathrm{a}}$ & & $20.56^{\mathrm{b}}$ & $26.68^{\mathrm{a}}$ & & $6.22^{\mathrm{b}}$ & $11.00^{\mathrm{a}}$ & \\
\hline CD (Season) & & 0.49 & & & 0.58 & & & 0.47 & \\
\hline CD (Treatments) & & NS & & & 0.71 & & & 0.58 & \\
\hline $\begin{array}{l}\text { CD (Season × } \\
\text { Treatments) }\end{array}$ & & NS & & & 1.00 & & & 0.82 & \\
\hline
\end{tabular}

$\mathrm{T}_{1}: 30 \times 10 \mathrm{~cm} ; \mathrm{T}_{2}: 20 \times 10 \mathrm{~cm}$; T3: $10 \times 10 \mathrm{~cm} ; \mathrm{S}_{1}$ : July - September; $\mathrm{S}_{2}$ : October - December 
Table 5. Effect of spacing and season of sowing on yield parameters of coriander variety CO-4

\begin{tabular}{|c|c|c|c|c|c|c|}
\hline \multirow[t]{2}{*}{ Treatment/ Season } & \multicolumn{3}{|c|}{ Biomass yield plot $^{-1}\left(\mathrm{~g} \mathrm{~m}^{-2}\right)$} & \multicolumn{3}{|c|}{ Green leaf yield plot ${ }^{-1}\left(\mathrm{~g} \mathrm{~m}^{-2}\right)$} \\
\hline & $\mathrm{S}_{1}$ & $\mathrm{~S}_{2}$ & Mean & $\mathrm{S}_{1}$ & $\mathrm{~S}_{2}$ & Mean \\
\hline $\mathrm{T}_{1}$ & $63.47^{\mathrm{e}}$ & $244.51^{\mathrm{c}}$ & $153.99^{c}$ & $56.54^{\mathrm{e}}$ & $230.78^{c}$ & $143.66^{c}$ \\
\hline $\mathrm{T}_{2}$ & $138.57^{\mathrm{d}}$ & $642.10^{\mathrm{b}}$ & $390.33^{b}$ & $129.50^{\mathrm{d}}$ & $626.17^{b}$ & $377.83^{\mathrm{b}}$ \\
\hline $\mathrm{T}_{3}$ & $235.67^{c}$ & $1131.20^{\mathrm{a}}$ & $683.43^{\mathrm{a}}$ & $217.33^{c}$ & $1088.67^{a}$ & $653.00^{\mathrm{a}}$ \\
\hline Mean & $145.90^{\mathrm{b}}$ & $672.60^{a}$ & & $134.45^{\mathrm{b}}$ & $648.54^{a}$ & \\
\hline CD (Season) & & 24.07 & & & 23.39 & \\
\hline CD (Treatments) & & 29.48 & & & 28.65 & \\
\hline CD (Season $\times$ Treatments) & & 41.69 & & & 40.52 & \\
\hline
\end{tabular}

$\mathrm{T}_{1}: 30 \times 10 \mathrm{~cm} ; \mathrm{T}_{2}: 20 \times 10 \mathrm{~cm}$; T3: $10 \times 10 \mathrm{~cm} ; \mathrm{S}_{1}:$ July - September; $\mathrm{S}_{2}$ : October - December

by increasing inter nodal length under closer spacing. These results are in accordance with the findings of Amaglo et al. (2007) in Moringa oleifera leaves, Farooq (2013) in coriander and Venugopal (2006) in patchouli.

The effect of row spacing on biomass and herbage yield plot $^{-1}$ was highly significant. The highest biomass and herbage yield plot $^{-1}$ were realised in the spacing of $10 \times 10 \mathrm{~cm}$. As the row spacing decreased from $30 \mathrm{~cm}$ to $10 \mathrm{~cm}$, biomass yield plot $^{-1}$ increased from $153.99 \mathrm{~g}$ $\mathrm{m}^{-2}$ to $683.43 \mathrm{~g} \mathrm{~m}^{-2}$. Similarly, the herbage yield plot $^{-1}$ increased from $143.66 \mathrm{~g} \mathrm{~m}^{-2}$ to $653.00 \mathrm{~g}$ $\mathrm{m}^{-2}$. The number of plants increased with the decrease in row spacing and highest number of plants could be accommodated in closer spacing of $10 \times 10 \mathrm{~cm}$. Similar results were also recorded by Kaur (2019) in coriander and Asundi (2001) in Japanese mint.

Spacing had significant effect on the Vitamin C content of fresh leaves. The Vitamin C content varied from $45.29 \mathrm{mg} 100 \mathrm{~g} \mathrm{~g}^{-1}$ to $65.16 \mathrm{mg} 100$ $\mathrm{g}^{-1}$, irrespective of season. Highest Vitamin $C$ content was recorded in closer $(65.16 \mathrm{mg}$ $\left.100 \mathrm{~g}^{-1}\right)$ as well as medium (64.62 $\mathrm{mg} 100 \mathrm{~g}^{-1}$ ) spacings. It could be due to the increased leaf temperature in wider spaced plants. Mahendran and Bandara (2000) reported the decrease in Vitamin C content of chilli fruit (Capsicum annuum L.) due to high leaf temperature.

Table 6. Effect of spacing on quality parameters of coriander variety CO-4

\begin{tabular}{|c|c|c|c|c|c|c|c|c|c|}
\hline \multirow[t]{2}{*}{ Treatment/ Season } & \multicolumn{3}{|c|}{$\begin{array}{l}\text { Vitamin C content } \\
\quad\left(\mathrm{mg} 100 \mathrm{~g}^{-1}\right)\end{array}$} & \multicolumn{3}{|c|}{$\begin{array}{c}\text { Volatile oil content } \\
(\%)\end{array}$} & \multicolumn{3}{|c|}{$\begin{array}{c}\text { Total chlorophyll } \\
\left(\mathrm{mg} \mathrm{g}^{-1}\right)\end{array}$} \\
\hline & $\mathrm{S}_{1}$ & $\mathrm{~S}_{2}$ & Mean & $\mathrm{S}_{1}$ & $\mathrm{~S}_{2}$ & Mean & $S_{1}$ & $\mathrm{~S}_{2}$ & Mean \\
\hline $\mathrm{T}_{1}$ & $29.26^{f}$ & $61.33^{c}$ & $45.29^{b}$ & 0.1 & 0.1 & 0.1 & $1.223^{\mathrm{e}}$ & $2.169^{c}$ & $1.696^{b}$ \\
\hline $\mathrm{T}_{2}$ & $43.90^{\mathrm{e}}$ & $85.33^{\mathrm{a}}$ & $64.62^{\mathrm{a}}$ & 0.1 & 0.1 & 0.1 & $1.326^{\mathrm{d}}$ & $2.447^{a}$ & $1.887^{\mathrm{a}}$ \\
\hline $\mathrm{T}_{3}$ & $54.32^{\mathrm{d}}$ & $76.33^{b}$ & $65.16^{a}$ & 0.1 & 0.1 & 0.1 & $0.957^{\mathrm{f}}$ & $2.183_{b}$ & $1.570^{c}$ \\
\hline Mean & $42.49^{b}$ & $74.22^{\mathrm{a}}$ & & 0.1 & 0.1 & & $1.169^{\mathrm{b}}$ & $2.266^{a}$ & \\
\hline CD (Season) & & 1.31 & & & NS & & & 0.007 & \\
\hline CD (Treatments) & & 1.60 & & & NS & & & 0.009 & \\
\hline $\begin{array}{l}\text { CD (Season } \times \\
\text { Treatments) }\end{array}$ & & 2.26 & & & NS & & & 0.013 & \\
\hline
\end{tabular}

$\mathrm{T}_{1}: 30 \times 10 \mathrm{~cm} ; \mathrm{T}_{2}: 20 \times 10 \mathrm{~cm}$; T3: 10 x $10 \mathrm{~cm} ; \mathrm{S}_{1}$ : July - September; $\mathrm{S}_{2}$ : October - December 
Spacing did not influence essential oil content in the leaves. This might be due to the negligible quantity of essential oil in coriander leaves compared to seeds. The total chlorophyll content was highest under medium spacing of $20 \times 10 \mathrm{~cm}$ followed by $30 \times 10 \mathrm{~cm}$. This could be due to the light effect, more light will be intercepted by wider spaced plants which could have helped in profuse vegetative growth and more synthesis of chlorophyll.

\section{Effect of growing season}

The growth, yield and quality parameters of coriander variety CO-4 varied between the seasons, irrespective of seed treatment and spacing. The growth parameters such as plant height and number of leaves plant ${ }^{-1}$ were found to be highest during October December. This increase in growth parameters were reflected in the yield parameters such as biomass and herbage yield plot $^{-1}$ at the time of harvest (Fig. 1). There was 4.79 and 5.10 fold increase in biomass and herbage yield plot $^{-1}$ respectively during October - December compared to July - September. Growing season plays an important role in all seed spices including coriander and there are reports indicating off season cultivation negatively affect the quantity and quality of coriander. Findings of the present study are also in line with the observations of Mohanalakshmi et al. (2019), Singh et al. (2000), and Meena et al. (2006) in coriander. The quality parameters also varied between the two growing seasons. Highest vitamin C content (Fig. 2) and highest total chlorophyll content in the leaf were recorded in the October - December crop. The vitamin C content increased by 109.54 per cent during October - December. The better growth parameters observed in the October December season might have influenced the production of more metabolic compounds in coriander leaves leading to higher quality. Total rainfall received, number of rainy days and the relative humidity were lower during October - December when compared to July - September season. On the other hand, the total sunshine hours recorded was more during October - December. Favourable effect of these weather parameters also might have contributed to the better growth and yield of coriander during this season. The October December season, where the quantum of light is more might have added to the improved Vitamin C content in leaves. Similar opinion was also given by Mohanalakshmi et al. (2019). Oyama et al. (1999) reported that ascorbic acid concentration increases with increased exposure to light, particularly in leafy greens such as spinach. The essential oil content did not vary with the seasons. This might be due to the negligible quantity of essential oil present in the coriander leaves as observed by Mohanalakshmi et al. (2019).

\section{Interaction effect}

The interaction effect of two factors i.e., seed treatment and spacing with the season of growing was also worked out from the data.

\section{Seed treatment $x$ season}

The interaction effect of seed treatments and season on yield was found to be significant. Highest biomass and herbage yield plant ${ }^{-1}$ was recorded in a combination of hydropriming for $24 \mathrm{~h}$ and October - December season. Highest vitamin $C$ content was recorded in a combination of $\mathrm{GA}_{3} 50 \mathrm{ppm}$ and October December season.

\section{Spacing $x$ season}

The interaction effect of spacing and season too was significant with respect to biomass and herbage yield plot $^{-1}$. Highest biomass and herbage yield $^{-1}$ were obtained when plants were grown in closer spacing of $10 \times 10 \mathrm{~cm}$ during October - December. Vitamin C content was highest in medium spacing during the same season.

In conclusion, the present study revealed that, rain shelter cultivation of coriander during October - December is ideal under tropical moist humid conditions for obtaining 


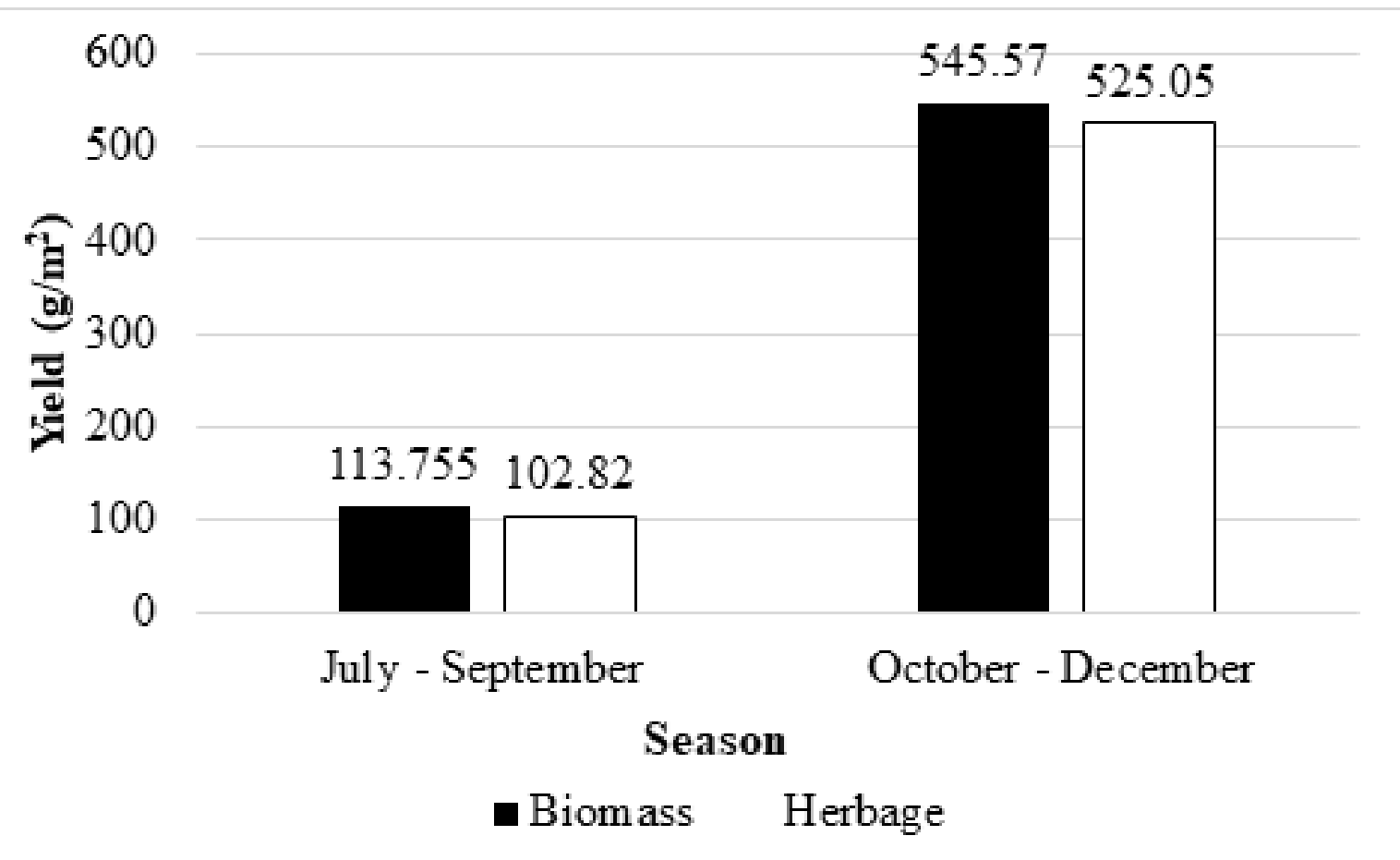

Fig.1. Effect of growing season on yield parameters of coriander variety $\mathrm{CO}-4$

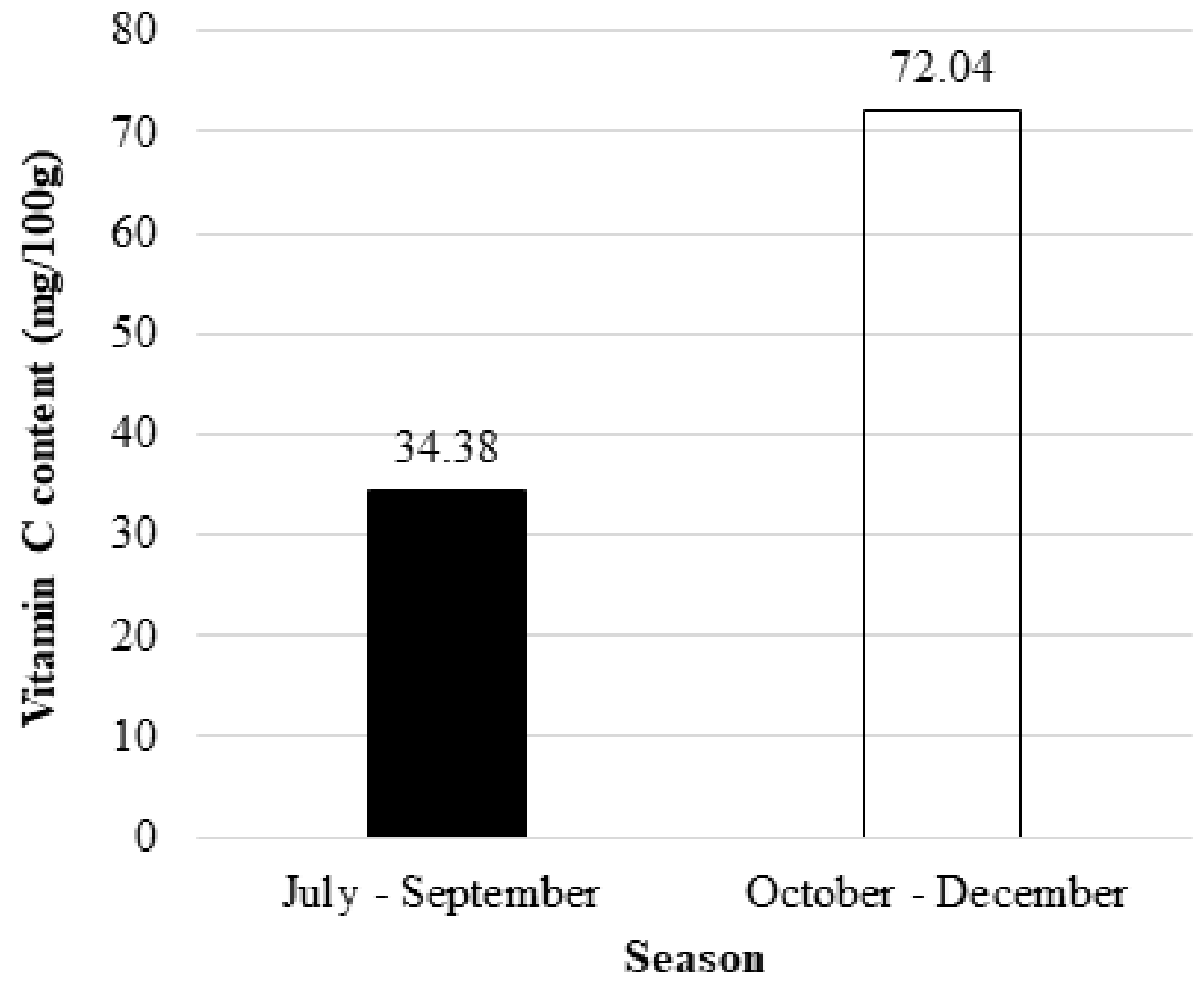

Fig.2. Effect of growing season on vitamin $\mathrm{C}$ content of coriander variety $\mathrm{CO}-4$ 
maximum herbage yield. Hydropriming for 24 hours and $\mathrm{GA}_{3} 50$ ppm for 8 hours can be used as presowing seed treatments for increasing the growth and yield. A closer spacing of $10 \mathrm{x}$ $10 \mathrm{~cm}$ is ideal for obtaining maximum biomass and herbage yield from an unit area.

\section{References}

Amaglo N K, Timpo G M, Ellis W O, Bennett R N \& Foidl N 2007 Effect of spacing and harvest frequency on the growth and leaf yield of moringa (Moringa oleifera Lam) a leaf vegetable crop. Ghana J. Hort. 6: 33-40.

Asundi J A 2001 Effect of row spacing and nitrogen levels on growth biomass and oil yield of Japanese mint (Mentha arvensis L.), M. Sc. (Ag.) thesis, University of Agricultural Sciences, Dharwad, 137p.

Bano U, Khan A, Mujeeb F, Maurya N, Tabassum H, Siddiqui M H, Haneef M, Osama K \& Farooqui A 2016 Effect of plant growth regulators on essential oil yield in aromatic plants. J. Chem. Pharm. Res. 8: 733-739.

Clevengers J F 1982 Apparatus for determination of volatile oil. J. Am. Pharmacol. Assoc. 17: 346-348.

Cornea-Cipcigan M, Pamfil D, Sisea C R \& Margaoan R 2020 Gibberellic acid can improve seed germination and ornamental quality of selected Cyclamen species grown under short and long days. Agron. 10: 1-19.

Farooq M 2013 Evaluation of genotypes and standardization of production technology in coriander, Ph. D (Hort.) thesis, University of Agricultural Sciences, Dharwad, 145p.

Finkelstein R, Reeves W, Ariizumi T \& Steber C 2008 Molecular aspects of seed dormancy. Annu. Rev. Plant Biol. 596: 387-415.

Haokip C M, Sharangi A B, Debbarma K, Devi A K R \& Karthik C S 2016 Role of plant growth regulators on the growth and yield of coriander (Coriandrum sativum L.). J. Crop Weed 12: 33-35.

Hiscox J D \& Israelstam G F 1979 A method for the extraction of chlorophyll from leaf tissue without maceration. Canadian J. Bot. 57: 1332-1334.
Jangid G, Mandal G, Mandal K K \& Thokchom R 2018 Foliar application of plant growth regulators to improve fruit retention, yield and quality of aonla cv. NA-7. J. Pharmacogn. Phytochem. 7: 21-26.

Kaur H 2019 Effect of row spacing and leaf cutting on seed yield and contributing traits in coriander, M. Sc. (Hort.) thesis, Punjab Agricultural University, Ludhiana, 77p.

Kumar R, Bakshi M \& Singh D B 2012 Influence of plant growth regulators on growth, yield and quality of strawberry (Fragaria $x$ Ananassa Duch.) under U. P. subtropics. The Asian J. Hort. 7: 434-436.

Kumar S, Malik T P, Mor V S \& Kumar P 2018 Effect of gibberellic acid on seed quality of coriander (Coriandrum sativum L.). J. Pharmacogn. Phytochem. 7: 830-832.

Mahendran S \& Bandara D C 2000. Effects of soil moisture stress at different growth stage on vitamin $C$, Capsicin and $\beta$ carotene contents of chilli (Capsicum annuum L.) fruits and their impact on yield. Tropic. Agric. Res. 12: 95106.

Maroufi K, Farahani H A \& Moaveni P 2011 Effect of hydropriming on seedling vigour in spinach (Spinacia oleracea L.). Adv. Environ. Biol. 5: 2224-2227.

Meena S S, Sen N L \& Malhotra S K 2006 Influence of sowing date, nitrogen and plant growth regulators on growth and yield of coriander (Coriandrum sativum L.). J. Spices Arom. Crops 15: 88-92.

Mishriky J F 1990 Response of celery (Apium graveolens var. dulce) to foliar application of gibberellic acid (GA3). Bull. Fac. Agri. 41: 777-784.

Mohajeri F, Ramroudi M, Taghvaei M \& Galavi M 2017 Effect of seed priming on chlorophyll content and yield components of pinto beans. Int. J. Biol. Pharm. Allied Sci.

Mohanalakshmi M, Boomiga M \& Gowtham T 2019 Effect of season and growing condition on yield and quality of parameters of coriander (Coriandrum sativum L.). Int. J. Chem. Stud. 7: 2989-2993.

Nouman W, Siddiqui M T, Basra S M A, Afzal I \& 
Rehman HU 2012 Enhancement of emergence potential and stand establishment of Moringa oleifera Lam. by seed priming. Turk. J. Agric. For. 36: 227-235.

Ogbuehi H C, Amadi C A \& Ashilonu P 2013 Effect of seed hydropriming on dry matter production and yield of Bambara groundnut (Vigna subterraneam (L.) Verdc.) landrace. Glob. J. Biol. Agric. Health Sci. 2: 150-153.

Oyama H \& Shinolara Y I 1999 Effect of air temperature and light intensity on beta carotene concentration in spinach and lettuce. J. Japan. Soc. Hort. Sci. 68: 414-420.

Rao B S \& Deshpande V. Experimental Biochemistry: A Student Companion, I. K. International (P) Limited, New Delhi. 302p.

Singh A \& Singh H K 2017 Application of plant growth regulators to improve fruit yield and quality in Indian gooseberry (Emblica officinalis Gaertn.). J. Agrisearch 2: 20-23.

Singh J, Malik Y S, Thakral K K \& Mehla C P 2000 Effect of sowing time, nitrogen levels and leaf cutting on green and seed yield of coriander.
Haryana J. Hort. Sci. 29: 225-228.

Singh D, Singh P P, Naruka I S, Rathore S S \& Saktawat R P S 2012 Effect of plant growth regulators on growth and yield of coriander. Indian J. Hort. 69: 91-93.

Venugopal C K 2006 Performance of patchouli (Pogostemon patchouli Pellet.) as influenced by nitrogen, spacing, shade, growth regulators and harvest techniques, Ph.D. (Hort.) thesis, University of Agricultural Sciences, Dharwad, 131p.

Verma P 2002 Studies on effect of different plant growth regulators and their mode of application on growth, yield and quality of coriander (Coriandrum sativum L.) cv. RCr435. Ph.D. (Ag.) thesis, Maharana Pratap University of Agriculture Technology, Udhaipur. 169p.

Zarei I, Mohammadi G, Sohrabi Y, Kahrizi D, Khah E M \& Yari K 2011 Effect of different hydropriming times on quantitative and qualitative characteristics of chickpea (Cicer arietinum L.). African J. Biotechnol. 10: 1484414850. 